\title{
16. \\ SPLIĆANI I SPLITSKE TEME U BEOGRADSKOJ JAVNOSTI 1920-1941 (POLITIKA I SRPSKI KNJIŽEVNI GLASNIK)
}

\section{Stanislava Barać}

UDK: 070(497.11 Beograd):304(497.5 Split)“193“

Izvorni znanstveni članak

Sažetak: Rad ima za cilj da istraži koliko su i na koji način, kao tema i akteri/autori, u beogradskoj javnosti tokom međuratnog perioda bili zastupljeni grad Split i njegovi stanovnici odnosno značajne kulturne ličnosti koje su tada ostavljale određenog traga u Splitu. Pojam beogradska javnost je specifično definisan i ograničen u skladu sa činjenicom da je tema rada podređena proučavanju „splitskog“, „formativnog razdoblja“ Vladana Desnice, koje je on, uz boravke na univerzitetima u Zagrebu (1924-1930) i Parizu (1927/1928), proveo pretežno u Splitu. Istraživanje se zato ograničava na dva beogradska periodika (Politika i Srpski književni glasnik) koji su bili izuzetno čitani u Dalmaciji i u porodici Desnica, i koji su imali odjeka i kod samog V. Desnice, pri čemu je simptomatično da se ni u jednom od njih Desnica nije ostvario kao saradnik. Cilj rada je, takođe, da istraži da li je slika Splita i Splićana koja se iz članaka ovih periodika ocrtavala posredno uticala i na pokretanje jedinog periodičkog projekta V. Desnice, Magazina Sjeverne Dalmacije (1934/1935), tačnije na njegovo koncipiranje ideje o potrebi posebnog glasila za posebnu jugoslovensku regiju. Pitanja koja se nameću jesu koliko je V. Desnica pisanja o Splitu i Splićanima u beogradskoj javnosti doživljavao kao sliku koju centar formira o periferiji, a koliko je beogradska javnost Split ipak prepoznavala kao jedan od jugoslovenskih centara koji se upravo u to vreme intenzivno razvijao. U radu se nije pošlo od „centra“ $\mathrm{i}$ od stanja u beogradskoj štampi, već od pojava i ličnosti koje su u datom periodu bile važne samim Splićanima i o kojima je intenzivno pisala lokalna štampa. Cilj je ispitati koliko su ove teme prisutne u Politici i $S K G$-u, kao i to da li su uloge njihovih komentatora i tumača preuzimali isključivo beogradski intelektualci i novinari ili je glas dodeljivan i Splićanima.

Ključne reči: Split, Splićani, Vladan Desnica, beogradska javnost, Politika, Srpski književni glasnik

\section{UvOD}

istraživanju slike Splita i učešća Splićana u beogradskoj javnosti učinjen je svojevrsni inverzni metodološki postupak, jer se, s obzirom na temu, nije pošlo od „centra“ i od stanja u beogradskoj štampi, već od „periferije“. Referentni okvir splitskih tema i lično- 
sti za kojima se traga u izabranoj beogradskoj periodici uspostavljen je pomoću tri „splitska“ izvora: 1) Bibliografija o Splitu. Dio 2: Od 1860. - 1955. godine Duška Kečkemeta (Split, 1956), 2) Znameniti i zaslužni Splićani te spomena vrijedne osobe u splitskoj povijesti (1700 godina) Petra Požara (Split, 2001) i 3) Grad i ljudi: Split 1918. - 1941. Zdravke Jelaske Marijan (Zagreb, 2009). Polazeći, dakle, od pojava i ličnosti koje su u datom periodu bile važne samim Splićanima i o kojima je pisala lokalna štampa (Kečkemetova bibliografija zasniva se najviše na splitskoj periodici), odnosno koje važnima smatra i nauka, istraživali smo koliko su one prisutne u Politici i Srpskom književnom glasniku, ${ }^{1}$ kao i to da li su uloge njihovih komentatora i tumača preuzimali isključivo beogradski intelektualci i novinari ili je glas arbitara davan samim Splićanima. U tom ključu, izdvajaju se članci koji pominju Tomu Rosandića, Don Frana Bulića, Ignjata Joba, Milana Begovića, Tina Ujevića, Niku Bartulovića, Iva Tartalju, Marina Tartalju, Vladimira Čerinu, Ivana Meštrovića i druge, kao i oni koji su bili deo intenzivne rasprave o tada podjednako intenzivnoj urbanizaciji Splita, posvećeni posebnim problemima poput podizanja spomenika Grguru Ninskom i izgradnje zgrade Banovine, događaju kakav je bio doček posmrtnih ostataka Kralja Aleksandra I Karađorđevića, oslobođenju Splita, kao i članci o Splitu kao najvećoj jugoslovenskoj luci i „glavnom gradu Dalmacije“.

Politika je, kao dnevni i jugoslovenski list, a negujući instituciju dopisništva, izveštavala o gotovo svim događajima iz Splita koji su tretirani bilo kao uzgredne vesti bilo kao velike naslovne priče, odnosno pisala je o splitskim temama koje su uobličavane u članke u rasponu od izveštaja preko reportaže do intervjua i polemike. ${ }^{2}$ Iako je u Politici upadljiv izrazito pozitivan stav prema Splitu kao gradu posebne državnostrateške važnosti, a zatim i gradu posebne lepote i fascinantnog urbanizacijskog napretka (koji po svemu sudeći dominira u ukupnoj beogradskoj javnosti), ${ }^{3}$ na njenim će se stranicama krajem 30-ih godina 20. veka pojaviti i oprečni pogledi. Oni se mogu shvatiti i kao (ne)posredna posledica pritisaka kojima je od 1937. Politika sve snažnije izlagana a sve teže odolevala.

Govoreći o „tri života Politike“, Dušan Đurić njen drugi život omeđava 1. septembrom 1919. i 6. aprilom 1941. Taj period obeležen je, posebno od proglašenja Obznane, cenzurom štampe i Đurić ga vidi kao „dve decenije nadmudrivanja sa cenzurom“, ali i vreme prosperiteta:

Između dva rata „Politika“ je okupljala najbolje novinare, a na stupcima lista uvek je bilo više informacija nego u drugim dnevnicima (...). I kad su vlade sredinom tridesetih godina počele zaokret ka Nemačkoj, „Politika“ je uspevala da očuva demokratsku orijentaciju, čak

\footnotetext{
U daljem tekstu $S K G$.

2 Dosledno prenoseći vesti dopisnika iz Splita, Politika je izvestila i o jednom „splitskom“ lomljenju ruke. To je, istina, bio lom ruke splitskog biskupa Klementa Bonefačića. On je, boraveći u Čakovecu sa koadjutorom Stepincem, silaskom sa kočija pao i slomio desnu ruku u zglobu ramena. Prenet je u banovinsku bolnicu gde se predviđa da će se lečiti narednih nekoliko nedjelja. Videti: Политика (Beograd), br. 9432, 21. 08. 1934., 10. Iako vesti ovoga tipa jesu nužni deo svih dnevnih novina, ova vest upravo „suvišnošću“ svoga obaveštenja svedoči o važnosti Splita za urednike Politike.

3 Vidi: А. Тодоровић, „Сплит као град велике будућности“, Време (Beograd), br. 5314, 30. 10. 1936., 6. Isto viđenje Splita imali su i oni, kako primećuju D. Roksandić i I. Cvijović Javorina, koji su u njemu živeli ili se u njega međuratnih godina doseljavali. Vidi: Drago Roksandić - Ivana Cvijović Javorina, „Riječ unaprijed“, Vladan Desnica i Split 1920. - 1945. Zbornik radova sa znanstvenog skupa Desničini susreti 2014, Zagreb 2015., 9.
} 
da izrazi antifašistički stav, naročito u izveštavanju iz Etiopije i u tekstovima iz španskog građanskog rata. Povremeno su urednici i bez izvornih „Politikinih“ izveštaja iskazivali ocene. Na primer, nadnaslov iz Španije glasio je „Međunarodni rat na španskom tlu“. Time se otvoreno ukazivalo da nije reč samo o međusobnim sukobima Španaca, nego o direktnoj vojnoj intervenciji Hitlera i Musolinija protiv legalno izabrane vlade Španije, u čiju odbranu su prispeli borci interbrigada iz celog sveta. (...) U redakciji je vladao višestranački pluralizam, a na zahtev ministra unutrašnjih poslova otpuštani su samo komunisti (Aleksa Markišić, dr Oton Krstanović, Čeda Kruševac, članovi KPJ, Vladimir Dedijer, simpatizer Partije) i poneki radikalniji liberal (Živojin Balugdžić); svi za 1. maj 1937. godine. ${ }^{4}$

U Srpskom književnom glasniku, pak, u skladu sa vrstom i koncepcijom periodika, pažnja se poklanja manje samom gradu i događajima (izuzev pozorišnim i uopšte kulturnim), a više analizi umetničkih dela autora koji su značajno (bili) vezani (i) za Split. Pored redovnih beogradskih saradnika, poput Isidore Sekulić i Branka Popovića, koji su pisali o Tomi Rosandiću i Marinu Tartalji, $S K G$ je, na primer, prostor ustupao i Splićanima kada je o tipično splitskoj temi bila reč, pa je tako nekrolog-portret Don Frane Bulića pisao Mihovil Abramić, Bulićev prijatelj i kolega arheolog.

U tom smislu, mogla bi se, u okviru koji uspostavljaju Politika i $S K G$, izdvojiti tri toka u pisanju o Splitu i Splićanima: jedan koji bi objedinjavao tekstove koji tematizuju odnos centra i periferije, prestonice i provincije; drugi koji bi se mogao nazvati polemičkim, a koji se bavi specifično splitskim urbanističkim temama; i treći, koji se odnosi na pojedinačne splitske umetnike i stvaraoce, i njihova konkretna ostvarenja.

Šira građa navodi čak na zaključak da je u međuratnom periodu uspostavljen poseban „prostor“ koji bi se uslovno mogao okarakterisati kao splitsko-beogradska odnosno beogradsko-splitska (literarna) javnost. Jasan i sažet trag ovog fenomena predstavlja Jadranska antologija Nika Bartulovića objavljena 1934. godine u Splitu. Naslov na koricama dat je latinično, dok se unutar knjige kombinuju latinica i ćirilica. „Predgovor“ ovoj antologiji pesama o Jadranskom moru - čiji je cilj, kao i cilj društva Jadranska straža, da „pomorski mentalitet" razvije kod svih Jugoslovena - (pot)pisan je u Beogradu, u kom Splićanin Bartulović od 1930. godine i živi. Uz to, u poslednjem pasusu Bartulović napominje da je za predgovor upotrebio sopstvenu studiju „More u našoj književnosti“, štampanu najpre u Beogradu, u SKG-u (1924) a zatim kao posebno izdanje Jadranske straže u Splitu (1927). ${ }^{6}$ Ovakvo cirkulisanje jednog teksta između beogradskih i splitskih publikacija nije incidentan slučaj (dovoljno je pomenuti samo poseban odnos splitskog lista Novo doba sa Beogradom), ${ }^{7}$ već izraz i agens pomenutog splitsko-beogradskog javnog prostora koji se jasno izdvaja i raspoznaje u okvirima jugoslovenske javnosti.

\footnotetext{
Dušan ĐurIć, „Politika“, Novinarska enciklopedija (ur. Dušan Đurić), Beograd 1997., 527-528.

5 Bartulović je najvećeg traga u ovom gradu ostavio kao profesor splitske gimnazije, direktor splitskog pozorišta (19211926) i autor drame pisane za tu pozornicu (Bijedna Mara. Drama u 4 čina prema eposu Luke Botića, Split 1922).

6 Niko Bartulović, Jadranska antologija, Split 1934., 37.

7 U izvanrednoj studiji o Novom dobu I. Kuić opisuje i prepiskom urednika dokumentuje ovu problematiku. Videti: Ivanka KuIć, „Novo doba - najvažniji splitski i dalmatinski list između dva rata“, Kulturna baština, 39/2013., 113-138. Posebno su značajna pisma Vinka Kisića iz 1926. u kojima se dogovara o zajedničkoj telefonskoj centrali u Beogradu sa koncernom Jugoštampa, i pritom iskazuje bliskost politici Ljube Davidovića i njegove Demokratske stranke, što je i „prva izjava o političkim preferencijama Novog doba u Kisićevo vrijeme“ (Isto, 118-119). One se nastavljaju i u vreme uredništva Vinka Brajevića, ali sa nešto složenijim odnosima Davidović - Brajević. Te preferencije
} 


\section{Šta Je Split Beogradu?}

Nesumnjivo je da je redakcija Politike izrazila i svoj stav prema Splitu kada je na povlašćenom mestu, na jednoj naslovnoj strani iz 1922. godine, objavila putopisnu reportažu „povlašćenog“ jugoslovenskog putopisca Marka Cara, „Utisci iz Splita“, određenu kao „pisma s mora“. „Split je u ovom trenutku varoš koja živi mahom u budućnosti“, ocenjuje Car: „U teoriji, i kao po nekom aktu samoodređenja, on je sebi namenio ulogu trećeg kulturnog i ekonomskog centra u sklopu nove države. Posle Beograda i Zagreba - veli se ovde - ima da dođe odmah Split. “8 Car usvaja ovaj san Splićana o Splitu, budućnost proglašava važećom, pa u završnoj rečenici njegove reportaže Split već jeste treći po važnosti grad jugoslovenske kraljevine. Split je, štaviše, „po važnosti treća, a po lepoti prva varoš na Slovenskom Jugu“. Opisujući prirodne lepote Splita, diveći se Marjanu, mediteranskom rastinju i mirisima, putopisac-reporter tvrdi da se

(...) ne da zamisliti mesto u većoj harmoniji sa sredinom u kojoj se nalazi i sa ljudima koji u njemu žive, kao što je to slučaj Splita. Zagreb i Ljubljana mogli bi da se prenesu negde u Nemačku, pa da opet ne odudaraju od svoje sredine... Sarajevo bi moglo da se nađe i na obali Nišave. Split, naprotiv, kao god i dalmatinsko vino i ulje, plod je naročitog zemljišta, koje mu daje i naročiti ukus. Split je, dakle, karakterističan kao Amsterdam, Venecija ili Neapolj.

I za druge intelektualce koji su živeli i boravili u Splitu nisu strana ovakva poređenja, pa je za Tina Ujevića Split uporediv sa Barselonom. ${ }^{10}$ Marko Car opisuje i život Splita, posebno večernji, na Rivi, koji traje sve do ponoći, ali i onaj dnevni, na kupalištu Bačvice. Da autor piše najviše za beogradske čitaoce, za one koji ne poznaju i ne razumeju Mediteran, otkriva rečenica u kojoj se iznosi: „Primetio sam više puta kako naši ljudi u Beogradu, kad je govor o letovanju u Primorju (koje ih, uostalom, jako privlači), ne mogu da se otmu izvesnom zaziranju, i kao nekoj bojazni od primorske vrućine. "11 Careva je identitetska pozicija i tačka gledišta u ovome članku, dakle, dvostruka: to je i pozicija Dalmatinca/Mediteranca i pozicija kontinentalca, odnosno i splitska i beogradska.

O tome da u Beogradu postoji fascinacija Splitom, i zato potreba da se o njemu piše, svedoči činjenica da pet godina kasnije, kao „Pisma s Jadrana“, Politika objavljuje sličnu splitsku reportažu Marka Cara, „Grad carskih letovanja“, sa podnaslovom „U Splitu, gde je nekada svoja leta odmora provodio rimski car Dioklecijan, i danas se carski letuje“. ${ }^{12}$

nisu, međutim, uticale na istovremenu vanstranačku koncepciju lista, tj. nisu bile vidljive u samim člancima. $U$ tom smislu, Kuićeva se poziva na formulaciju Tonćija Šitina o „srednjem putu Novog doba“ (Isto, 121).

8 Марко ЦАР, „Утисци из Сплита“, Политика (Beograd), br. 5130, 6. 8. 1922., 1-2. Videti i: Marko Car, „Utisci iz Splita“, Novo doba (Split), br. 182, 12.8. 1922., 2-3. Ova putopisna reportaža nije se našla u Carevoj knjizi $\mathrm{Na}$ še primorje (1923), u kojoj je autor preštampao stare primorske putopise (1910) i dodao im dva nova („Dalmacija $\mathrm{i}$ Makarska“), jer je rukopis, kao što se vidi po datiranju piščeve „Napomene“, već bio zaključen jula 1922. godine.

10 D. RoKsandić - I. Cvijović Javorina, „Riječ unaprijed“, 9.

11 М. ЦАР, „Утисци из Сплита“, 1.

12 Марко ЦАР, „Град царских ьетовања“, Политика (Beograd), br. 6879, 24. 6. 1927., 7. Videti i: Marko CAR, „Grad carskih ljetovanja“, Novo doba (Split), br. 147, 27. 6. 1927., 2. 
Očigledno je da se u drugoj polovini dvadesetih godina o Splitu više ne može pisati izvan turističkih kategorija, ${ }^{13}$ pa i, s njima povezanog, reklamnog diskursa. ${ }^{14}$

Tekst je još jedna oda Splitu u novinarskoj formi, pisana sa osećajem za sve nijanse prirodnih lepota i harmoniju prirode i društvenog života grada, koja „ponositi divni beli grad Split“ predstavlja kao „večiti grad“. U doživljaju Marka Cara, Split je jedan veliki superlativ: „U ove dane vrelog leta Split je valjda najživlji grad u celoj našoj državi“; „Nigde mladost svoju srčanost nije toliko ulila u život jednog grada kao u Splitu“; „Najveći grad u Dalmaciji, prirodni, kulturni i politički centar njen“; „Sve lade koje plove našim morem stiču se u njemu“; „U njemu, kao što je već rečeno za Dubrovnik, ali što još višse važi za Split, svaki kamen ima svoju istoriju. A ovo 'kamenje' Splita zaista je najdragoceniji spomen divne istorije naše zemlje. Dioklecijanova palata je besumnje jedna od najvećih rimskih gra-

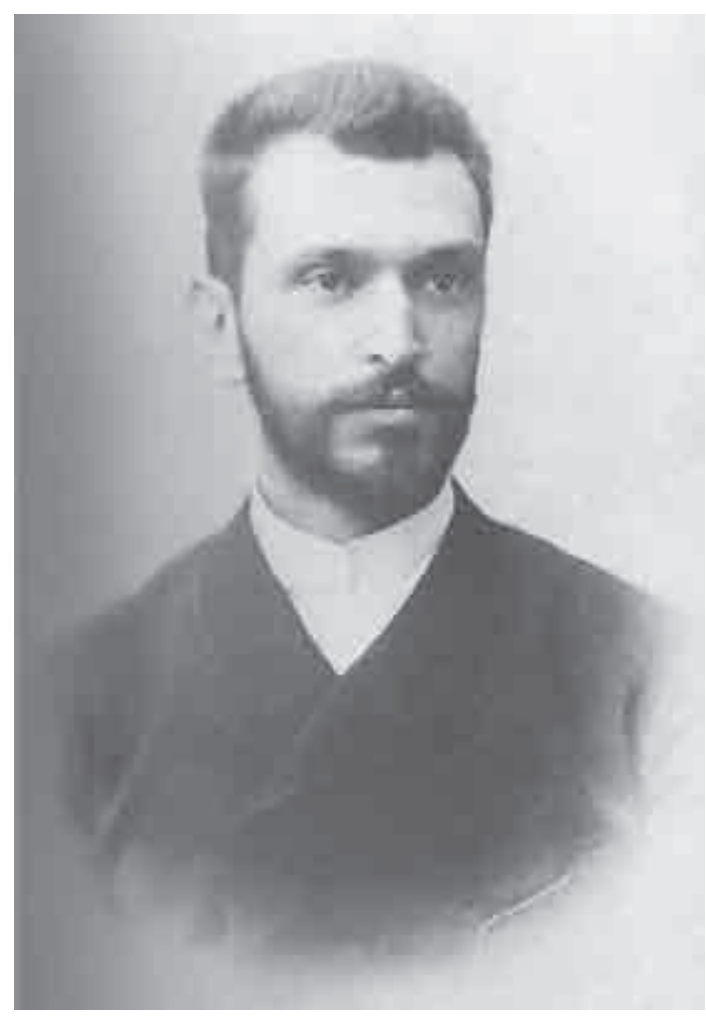

Sl. 1. Marko Car đevina koje su ovako dobro očuvane." U tom superlativnom tonu članak je i zaključen: „Iako je Split udoban za letovanje i privlačan za strance, ipak najveća njegova draž je u njegovoj okolini, najlepšoj, najidealnijoj okolini koju ijedan grad ima. ${ }^{\text {"15 }}$

U svemu su oprečni pozicija i utisci pisca i Politikinog redovnog saradnika Grigorija Božovića, jednog od poslednjih reportera iz Splita u Politikinom međuratnom periodu. Po mnogo čemu indikativan je njegov članak „U srećnijim prilikama“ sa nadnaslovom „Ispod Velebita i Dinare“ i podnaslovom „Utisci iz današnjeg Splita“. ${ }^{16}$ U ovom članku na delu je zapravo antimodernizacijski diskurs, u kome se mogu prepoznati sintaksičko-semantičke strategije u kritičkoj analizi diskursa poznate kao negacija prividne afirmacije i govor po modelu „da, ali“. One su realizovane najčešće tako što bi u drugom delu rečenice autor na neki način obezvredio i negirao ono što je kao „pozitivno“ izneo u prvom. Ako se u jednom momentu učini da se Božović svrstava u (puto)pisanja Cara i Ujevića kada kaže da „vilama

13 U međuratnom periodu, putopisni tekstovi su teško odolevali turističkom diskursu, čak i kod ovakvih autora koji su se još krajem 19. veka ostvarili kao putopisci. Videti: ВАаАимир ГВОЗАЕН, Српска путописна култура 19141940. Студија о хронотопичности сусрета, Beograd 2011.

14 I nezavisno od toga da li se piše o Splitu i primorskim mestima, reklamni diskurs postaje opšta odlika (srpskih) međuratnih putopisa i putopisnih reportaža. Videti: В. ГВОЗАЕН, Срnска nуmоnисна култура 1914-1940., $187-207$.

15 М. ЦАР, „Град царских метовања“, 7. Kurziv S. B.

16 Григорије БОЖОВИЋ, „Утисци из данашњег Спмита“, Политика (Beograd), br. 11181, 19. 7. $1939 ., 17$. 
Ivana Meštrovića i Tresića-Pavičića i Nica bi mogla pozavideti“, suprotna poenta usledi u narednim rečenicama:

Na Marjan su milioni utrošeni (...). Njegove staze su divno provedene i mnogo su koštale. (...) Pa se čovek još više obraduje kad baci pogled na brodogradilište i one mnoge i ogromne dimnjake prema njemu s one strane zaliva, koji se počeo graditi i na koji će se baciti koja stotina miliona. ${ }^{17}$

U celini, Božovićeve (implicitne) poruke jesu da je urbanizacija Splita zadivljujuća, ali da previše košta siromašnu zemlju, da se grad intenzivno razvija tek od (srpskog) oslobođenja, a da vrednosti Mediterana treba sameriti kontinentalnim Balkanom. Grigorija Božovića Split, naime, asocira - ne na Amsterdam, Veneciju ili Barselonu, već - na Skoplje, posebno pogledom sa Marjana. Sam članak se od „ode“ Splitu, kako su prve rečenice sugerisale, brzo pretvara u isključivo ruženje Splita i Splićana, sa sve većim izazivanjem neprijateljstva prema njima, završavajući kao da se svađa sa samim gradom, koji u njegovom tekstu i jeste jedna personifikovana figura:

A gunđa i kritikuje; traži tuđe odgovornosti, na svoje nikad ne pomišlja. Nezadovoljan je i sve mu je malo kao da sluti. Kao da kobi sebe i druge, jer onako sasvim uvereno misli da je on nešto najveće i najvažnije u Jugoslaviji, koja mu ne poklanja dovoljno pažnje. ${ }^{18}$

Taj stav autor pripisuje svim primorskim gradovima, a nemotivisano ubacuje i stihove narodne pesme kada opisujući istoriju grada tematizuje odbranu Splita od Turaka, što mu asocijacije dalje odvodi i do (mitskog) Kosova.

Božović iznosi tvrdnju da Austro-Ugarska nije dozvoljavala bilo kakav razvoj Splita: „Neka se u slobodi razvija dragi grad naš kojemu Austro-Ugarska nije dala ni da dahne." ${ }^{19}$ Ovakvo tumačenje bilo je u međuratnom periodu stereotip i opšte mesto medijskog diskursa i kao takvo se nekritički prenelo i na (kasniju) nauku. Međutim, Split je do početka Prvog svetskog rata već uveliko bio dalmatinski grad sa najvećim brojem stanovnika, većim čak i od Zadra, sa njihovim stalnim i stabilnim porastom još od 1880. godine. ${ }^{20}$ Već od 1880-ih Split postaje i privredni i nezvanični politički centar Dalmacije, sa jačanjem značaja splitske luke i usponom cementne industrije, odnosno od „pohrvaćenja Splitske općine 1882.“.21

I uopšte, kako iznosi Zdravka Jelaska Marijan u zaključku svoje knjige o društvenom razvoju međuratnog Splita:

(...) brzi razvoj Splita nakon Prvog svjetskog rata često se lakonski tumači kao posljedica pretvaranja Splita u upravno središte Dalmacije nakon što je Zadar došao pod talijansku vlast. Međutim, detaljniji uvid u tadašnju situaciju pokazuje da pretvaranje Splita u upravno središte i brzi razvoj grada nije bio ni jednostavna, ni nagla promjena, kako bi iz tako po-

\footnotetext{
17 Isto. Kurziv S. B.

18 Isto.

19 Isto.

20 Zdravka Jelaska Marijan, Grad i ljudi: Split 1918.-1941., Zagreb 2009., 26 i 30.

21 Isto, 490.
} 
jednostavljenog objašnjenja proizlazilo. Razvoj Splita u međuratnom razdoblju umnogome je posljedica razvojnih smjernica primjetnih već tijekom XIX. stoljeća, osobito u njegova dva zadnja desetljeća, te na početku XX. stoljeća. ${ }^{22}$

Iako se, prema ovom antiaustrougarskom stavu Božovićev članak naizgled uklapa i u projugoslovenske diskurse, Božovićev tekst zapravo je rezultat antijugoslovenskih i antimodernizacijskih tendencija koje su kasnih tridesetih u vidu ovakvih diskursa prodirale $\mathrm{u}$ izrazito jugoslovenski i liberalno na početku dvadesetih koncipiranu Politiku. U tom smislu posebno je zanimljiv nešto kasniji članak „Na današnji dan ušla je srpska vojska u Split“ autora St. Roce, čije je recepcijsko dekodiranje, čini nam se, moglo da bude dijametralno suprotno zavisno od toga ko ga je čitao, kao i gde ga je čitao. ${ }^{23}$ Ovaj članak objavljen je u posebnom intertekstualnom kontekstu, među člancima koji izveštavaju o ratu, mađarskom pristupanju Trojnom paktu i nacističkom bombardovanju Birmingema; kao i u posebnom kontekstu sve dominantnije profašističke politike Kneza Pavla.

21. novembra 1940. bilo se navršilo tačno dvadeset godina od ulaska srpske vojske u Split. Autor članka podseća da je

(...) Split plivao u oduševljenju jer mu dolaze vesnici slobode i jedinstva. I kad je osvanuo željeni dan, već jutrom rano, počeo je grad dobivati svečano lice i raspoloženje. (...) Na sredini obale slavoluk udešen grbovima naših pokrajina, ćirilskim natpisom: „Dobro došli“. 24

Roca podseća i na članak Ivana Meštrovića objavljen tom prilikom u londonskoj štampi. U Londonu je Meštrović tada boravio kao član Jugoslovenskog odbora, a pomenuti članak zaključio je rečima u slavu srpske vojske i Srbije. Tadašnji gradonačelnik Splita, dr Smodlaka, između svih hiperbolično iskazanih pohvala i blagoslova, obratio se srpskoj vojsci po iskrcavanju i rečima:

Vi već davno prekoračiste međe i male i velike Srbije. U ovom ste gradu danas daleko preko granica Dušanova carstva. Vi osvajate i stvarate novo, kudikamo veće i silnije carstvo: Jugoslaviju, zajedničku državu i majku našu. Ali i ovo je ipak sve Srbija vaša. Ovo je najveća Srbija - jer će Jugoslavija, koju vi svojom krvlju iskupiste biti sposobna i dostojna da živi samo dok bude imala duh vaše male Srbije, koja je vas rodila i naučila umirati za slobodu. ${ }^{25}$

Pitanje je, dakle, kako su ove reči 1940. godine mogle da odjekuju u Srbiji i u Hrvatskoj, u Beogradu i u Splitu. ${ }^{26}$ Podsećanje na oslobođenje Splita kao jedan od ključnih događaja u konačnom definisanju jugoslovenske države, moglo je da bude čitalački dekodirano kao poziv na očuvanje jugoslovenskog jedinstva u trenutku nove velike opasnosti spolja i raskola iznutra, ali isto tako i kao etnocentrični diskurs koji prenaglašava ulogu Srbije. Grad Split dobio je u trenucima dezintegrisanja jugoslovenske kraljevine isto značenje i značaj koje

\footnotetext{
Isto, 479 .

23 Ст. РоцА. „На данашњи дан ушла је српска војска у Спиит“, Политика (Beograd), br. 11664, 21. 11. $1940 ., 6$.

24 Isto. O srpskoj vojsci u Splitu Roca piše i u splitskoj Jadranskoj straži 1923. i Almanahu Jadranske straže 1926. Videti: Duško Kečkemet, Bibliografija o Splitu. Dio 2: Od 1860-1955. godine, Split 1956.

25 Ст. РоцА. „На данашњи дан ушла је српска војска у Спиит“, 6.

26 One su u svakom slučaju morale imati velikog odjeka, jer je tiraž lista Politika u tom trenutku iznosio 145000 primeraka. Videti: D. Đurıć, „Politika“, 528.
} 
je imao i u trenucima njenog konstituisanja: značenje povlašćenog simboličkog prostora i diskurzivnog polja unutar koga se prelamaju dominantne ideološke i političke tendencije i sukobi u Jugoslaviji.

\section{URBANISTIČKE POLEMIKE}

Takve su se ideološke i političke tendencije upisivale i u samu arhitekturu grada, a tragove su ostavile i u vidu novinskih i časopisnih polemika. Samo je prividno ponekad stican utisak da je reč o lokalnom gradskom pitanju. Polemika koja se povela oko mesta na koje će biti postavljen Meštrovićev spomenik Grguru Ninskom obeležila je pre svega splitsku lokalnu štampu, odnosno splitsku javnost, dok u beogradskoj javnosti ideja da se veliki spomenik hrišćanskom svešteniku podigne u sred antičkog Peristila nije uskomešala tolike strasti niti je to i mogla na način kao u sredini koje se narušavanje urbanističkih celina (sopstvenog) grada tiče. Spomenik Grguru Ninskom na Peristilu svečano je otkriven 29. septembra 1929. godine. Politika tom događaju pridaje, naravno, izuzetnu važnost, objavljujući tekst tadašnjeg urednika splitskog Novog doba Vinka Brajevića na naslovnoj strani, a prenoseći ga i na sledeću. ${ }^{27} \mathrm{Za}$ režimski list od prvenstvene je važnosti činjenica da je spomenik podigao Knez Pavle. Spomenik je trebalo da podigne sam Kralj Aleksandar I Karađorđević, ali je zbog sprečenosti kao izaslanika poslao Kneza Pavla. Očigledno je da je splitski novinar ovde silom prilika bio prinuđen da se postavi u beogradsku i režimsku perspektivu. ${ }^{28}$ Iz perspektive Politike, čitav je događaj jedna velika svečana državna manifestacija, u kojoj su najvažniji govori visokih zvanica, a u tim govorima oni njihovi delovi koji podizanje spomenika Grguru Ninskom tumače kao izraz (južno)slovenske pobede u Dalmaciji, odnosno aktuelnog jugoslovenskog integralizma. Živoj raspravi koja je podizanju spomenika prethodila, a koja je pokrenula ključna pitanja urbanizacije (ne samo splitske) i razumevanja urbaniteta, u Politikinom članku nema ni pomena.

Međutim, problem arhitektonsko-urbanističkog narušavanja Peristila i čitavog kompleksa Dioklecijanove palate pojavio se ponovo, odlukom da Split postane centar Primorske banovine i da se, u skladu sa tim, u njemu podigne nova zgrada banovine, a za to je ponovo odabran isti prostor - ispred Dioklecijanove palate. Politika ovoga puta objavljuje polemički članak samog Splićanina dr Prvislava Grizogona „Gde da se podigne banovinska palata u Splitu?", sa upozoravajućim nadnaslovom „Pre nego bude kasno“ i podnaslovom „Prvi veliki spomenik Jugoslavije na Jadranu ne sme da bude unakaženje dvehiljadugodišnje Dioklecijanove palate“. ${ }^{29}$ Članak je, međutim, objavljen na molbu samog autora („zbog čega

\footnotetext{
27 В[инко] БРАЈЕВИЋ, „Кнез Павце је јуче открио споменик Гргуру Нинском у Спмиту“, Политика (Beograd), br. 7690, 30. 9. 1929., 1-2.

28 Štaviše, Brajević je i u samom Splitu još 1927. godine trpeo pritiske od gradonačelnika Iva Tartalje zbog kritičkog pisanja Novog doba o tada tek iznesenoj ideji o postavci Meštrovićevog spomenika na urbanistički neadekvatnom mestu. Videti: I. Kuić, „Novo doba“, 124-125.

29 Првислав ГРИЗОГОНО, „ГАе Аа се подигне бановинска палата у Сплиту“, Политика (Beograd), br. $10031,26$. 4. 1936., 10 .
} 
sam zamolio gostoprimstvo ovog uglednog prestoničkog lista"), a Grizogono u tekstu eksplicira i tematizuje i odnos centar - periferija, za koji zna da je kao vrednosni stav prisutan u beogradskoj javnosti povodom splitskih pitanja. „U ovom velikom urbanističkom pitanju provincijskog grada na Jadranu“ osnovni problem je, kako ga Grizogono definiše, sledeći:

Ispred Dioklecijanove palate namerava se da se podigne ogromna moderna palata za bansku upravu. Banovina, ogromna već po svojim potrebama, imala bi da bude dobrano viša od Dioklecijalnove palate, a zahvatila bi čitavu polovinu južne fasade njezine. Kako pak ta nova zgrada dolazi nekih sedamdesetak metara bliže moru nego palata, jasno je da bi ta ogromna četvorokutna masa ne samo sakrila polovinu fasade Dioklecijanove palate, nego i nepopravljivo poremetila ovu i do sada ne sasvim dobro očuvanu perspektivu. Čovek se u istini pita: ama, ima li zbilja neko prokletstvo pa tome Splitu, da, kad se nije uspelo već kroz nekoliko stotina godina da se podigne ama jedna lepa monumentalna zgrada, jednako namišljamo kako ćemo da unakazimo ono što smo, bez naše zasluge, kao lepo nasledili? ${ }^{30}$

Ukoliko se pak prihvati drugo, razumno rešenje, da se banovinska zgrada ne gradi odmah ispred palate, već na takođe istaknutom mestu, ali na kom ne zaklanja pogled na drugo kulturno nasleđe, ${ }^{31}$ onda, smatra Grizogono, takvo „najestetičnije“ rešenje ostalo bi trajno kao „veliki monument estetski stvaralačke snage mlade jugoslovenske $d r$ žave na ovome primorju“. 32

Grizogono smatra da je nužno ne samo da postoji javna rasprava, već da je sama država dužna da je pokrene iako je, kao što klasična Habermasova definicija javnosti ističe, javnost uperena (i) protiv same javne vlasti. Jirgen Habermas, kao što je poznato, određuje da se kritička (liberalna, građanska) javnost može shvatiti „kao sfera privatnih ljudi koji okupljeni čine publiku, njima je potrebna javnost regulisana propisima vlasti i od početka usmerena protiv same vlasti da bi sa ovom prečistili račune o opštim pravilima opštenja i principijelno

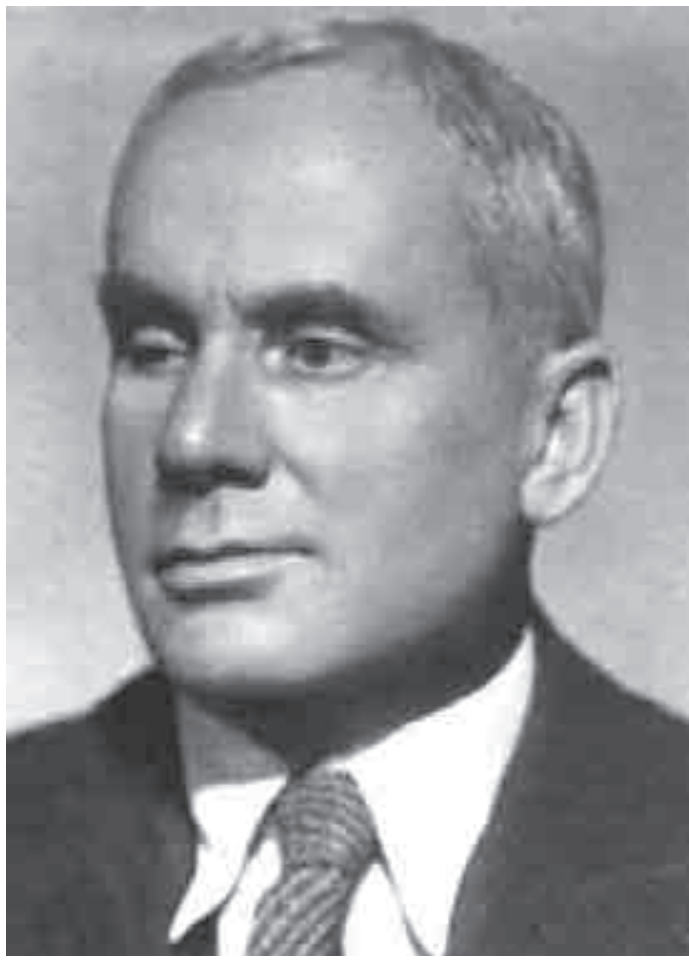

Sl. 2. Prvislav Grisogono privatizovanoj ali javno relevantnoj sferi robnog prometa i društvenog rada. Medijum ovog političkog obračuna je specifičan i istorijski bez presedana: javno rezonovanje“. 33

30 Isto. Kurziv S. B.

31 Misli se na rešenje arhitekata Senjanovića i Pičmana, po ideji Josipa Smodlake, koje je i bilo reakcija na neadekvatan predlog, a koje, na čemu insistira Grizogono, otkriva a ne zakriva Dioklecijanovu palatu u svoj njenoj lepoti, i čini harmoničan kompleks sa ostalim spomenicima i zgradama u okruženju.

32 П. ГРИЗОГОНО, „ГАе Аа се подигне бановинска памата у Сплиту“, 10. Kurziv S. B.

33 Jirgen Habermas, Javno mnjenje, Novi Sad 2012., 81. 
„Država je dužna“, piše Grizogono, „kako bi izbegla docnije opravdane prigovore, da nema smisla za velike kulturne zaostavštine prošlosti, da prethodno izazove mišljenje domaćih, pa i stranih stručnjaka." ${ }^{34}$ Zato Grizogono mora da se oglasi iz samog Beograda i sa stranica lista koji je „državni“. Po svemu bi se reklo da je Grizogono nehotični teoretičar javne sfere. Jer, pored ostalog Grizogono zapravo sve vreme insistira na tome da mesto i izgled banovinske zgrade nije lokalni splitski problem i tim povodom javnosti postavlja pitanje o njoj samoj:

Zašto imamo umetničke akademije, tolike fakultete, umetnička odeljenja? Zašto imamo u Beogradu, Zagrebu i u Ljubljani katedre za povest umetnosti, ako nikome ne pada na um da u jednome ovakvome pitanju, pre nego bude gotovo, zatraži mišljenje jednoga Ivana Meštrovića, jednoga dr. Šcajlera, jednoga Branka Popovića, Bogdana Popovića itd. ${ }^{35}$

Jedan od takvih koje sama država nije unapred ništa pitala, splitski, beogradski i jugoslovenski vajar Toma Rosandić, javlja se ubrzo u Politici tekstom još polemičkijeg i eksplicitnijeg naslova „Mora se sprečiti zidanje palate na mestu sa koga bi zaklonila polovinu Dioklecijanove palate" sa nadnaslovom "Jedan kulturno-istoriski problem“ i podnaslovom „Kako će se sagraditi banska palata u Splitu“ ${ }^{36}$ Rosandić ovim povodom reaguje, pre svega kao građanin Splita, pa je i njegov glas, uz Grisogonov, „autentični“ splitski glas unutar beogradske javnosti. Apelujući najdirektnije da se izabere pravo rešenje (Smodlaka - Senjanović - Pičman) i izjašnjavajući se pritom eksplicitno kao Splićanin, Rosandić je, reklo bi se uzgred, dao i svojevrsnu definiciju intelektualca: „Ja apelujem, i kao Splićanin i kao umetnik, a i kao onaj koji oseća velike dobiti i materijalne i moralne... “37

On Dioklecijanovu palatu smatra „vrlo osetljivom tačkom svetskog umetničkog - arheološkog nervnog sistema“, „svetskom svetinjom“, „,svetskim turističkim hodočašćem“, „opštečovečanskom svojinom“. Ono što je, pak, važno za ovu temu, to je činjenica da Toma Rosandić upućuje čitaoce Politike na nedavne članike Josipa Smodlake u splitskom listu Novo doba (uskršnji broj iste godine), kao i na Grizogonov članak u Politici. Reklo bi se da ovakvim pozivom Rosandić iznutra i eksplicitno „decentralizuje“ beogradsku javnost. Rosandić je uz to, poput Grizogona, nehotični i uzgredni teoretičar javnosti, jer i on izvlači opštiji zaključak iz konkretne situacije. Rosandićev stav je da oni koji rade na štetu narodnog, opšteg dobra treba da budu u tome sprečeni, a to će biti moguće samo „ako se u svakom poslu prvo sasluša javna reč“ ${ }^{\text {“c }} 38$

I sledeći Rosandićev članak na ovu temu, „Kako bi trebalo da izgleda narodni spomenik u Splitu“, objavljen već posle deset dana, reakacija je na Smodlakin članak iz Novog doba,

\footnotetext{
34 П. ГРИЗОГОНО, „ГАе Аа се подигне бановинска палата у Спииту“, 10. Isto. Kurziv S. B.

35 Isto.

36 Тома РОСАНТИЋ, „Мора се стречити зидање палате на месту са кога би закмонима половину Аиокмецијанове пакате“, Политика (Beograd), br. 10041, 7. 5. 1936., 13.

37 Isto.

38 U arhivi lista Novo doba nalazi se „pismo kipara Tome Rosandića, od 7. prosinca 1934., u vezi s inicijativom naših iseljenika za izgradnju spomenika Kralju ujedinitelju u Splitu“. Rad je trebao dobiti izravno Meštrović, bez natječaja. Rosandić se pobunio protiv takvih principa i stoga je molio Brajevića da napiše nešto o tome. Videti: I. Kuić, „Novo doba", 129 .
} 
ali ranijeg, od 1. januara 1935. Rosandić iznosi viziju koja mu se javlja na osnovu postojećeg Smodlakinog rešenja uređenja prostora oko Dioklecijanove palate. To je, bar na prvi pogled, jedna demokratska i demokratizujuća vizija Splita:

(...) celu obalu Francusku, Dioklecijanovu i $\check{S}(t)$ rosmajerovu udesiti tako da postane idejno jedna celina estetskog dejstva za prikupljanje naroda. Čitavu obalu od starog suda do proširenog dela Štrosmajerove obale podvrgnuo bih skuptorskoj i arhitektonskoj obradi - jednoj istoj idejnoj nameni, tako da sva obrada ima moć i karakter da izazove utisak zbornog mesta. To bih postigao unošenjem spomenika koji bi sa obradom sižea strogo pripadali uvek istoj nameni kojoj je zborno mesto namenjeno. ${ }^{39}$

Rosandić je, naime, imao ideju da na mestu tzv. Monumentalne česme postavi jedan spomenik Kralju Petru I Oslobodiocu i drugi Kralju Vitezu Aleksandru I Ujedinitelju, kako ih on naziva. Za njega su figure kraljeva samo stilske figure, personifikacije Oslobođenja i Ujedinjenja. Ti su spomenici „sveto narodno žarište za crpenje gordosti“. Opet je Rosandić i svojevrsni teoretičar javnosti, jer on smatra da ovaj njegov predlog mora da bude prethodno široko popularizovan, to jest da su u konačnu odluku o njegovom realizovanju uključene najšire narodne mase, a tek onda da bude i sproveden..$^{40}$

Isto tako, Rosandić je u ovom slučaju i ideolog integralnog jugoslovenstva. U tom se momentu, međutim, nalazi činilac suprotan deklarativnim demokratizujućim tendencijama i značenjima njegove vizije. Iako su, po zamisli Rosandića, statue kraljeva samo figure i personifikacije jugoslovenskog oslobođenja i ujedinjenja, one, posebno tako predimenzionirano zamišljene, u praksi neminovno funkcionišu u kontekstu kulta ličnosti. „Moć i karakter“ da se izazove „utisak zbornog mesta“, pod čim Rosandić podrazumeva slobodu javnog okupljanja (i mišljenja), nije isključiva osobina grandioznih urbanističko-arhitektonskih kompleksa, a posebno je problematična ideja da likovi vladara imaju takva svojstva. Još je problematičnija ideja da se ideološki - makar u vizuelnom smislu - neutralan spomenik, u vidu česme, zameni ideološki preopterećenim znakom/spomenikom, što figure srpskih kraljeva jesu bile još od osnivanja zajedničke Kraljevine, a posebno su to postale posle drastične kulminacije srpsko-hrvatskih političkih sukoba 1928. godine.

Ipak, nezavisno od ovog spornog elementa u jednom od članaka, splitska urbanistička polemika u Politici, u interakciji sa listom Novo doba, predstavljala je jednu od retkih otvorenih polemika u datim nepovoljnim uslovima za slobodu štampe i odigrala je izrazito (samo)osvešćujuću ulogu u odnosu na jugoslovensku čitalačku publiku. Upravo u trenucima kada je reč dala Splićanima i učestvovala u „splitskoj“ polemici, Politika, a sa njom i beogradska javnost, osvešćivala je i sopstvenu poziciju i ulogu, kroz rečenice koje čak anticipiraju kasnija teorijska promišljanja javnosti. U tim tekstualnim trenucima beogradska javnost postaje i dosledno jugoslovenska.

39 Т[ота] РОСАНТИЋ, „Како би требало да изгледа народни споменик у Сплиту“, Политика (Beograd), br. 10051, 17. 5. 1936., 9.

40 „Bez unošenja u delo javnih funkcija, masa narodna neće se nikada konstantno sa ljubavlju prema delu ophoditi, već će takvo delo, iako umetnički dobro, brzo zaboraviti, omrznuti i smatrati kao nešto što nije njeno, jer joj organski ne pripada, usled nerazumljivosti namene." Isto. 


\section{Umetnici Splićani - BeograĐani - Jugosloveni}

Analiziranim Rosandićevim člankom Politika je uglavnom i okončala splitsku urbanističku raspravu, ali vredi napomenuti da je sam Toma Rosandić već bio posebna tema lista, obrađena upravo iz naglašeno beogradske perspektive. U članku M. Radovanovića, „Jedan veliki naš umetnik“ (sa fotografijom T. Rosandića i Mauzoleja porodice Petrinović) iz 1927. godine, splitski je vajar viđen kao jedan od talentovanih ljudi koji iz drugih mesta pristižu u Beograd, koje Beograd privlači, ali koji isto tako menjaju i obogaćuju prestonicu: „Svojim dolaskom u Beograd g. Toma Rosandić uvećeva krug prestoničkih vajara. Njegova upadljiva i zanimljiva ličnost, njegov skulptorski dar pun snage i muškosti lako će se snaći u ovome gradu, koji sve više privlači naše umetnike iz različitih krajeva. "“1 Članak svedoči i o tome koliko su se u međuratnom periodu, iz beogradske perspektive, poistovećivali pripadnost Beogradu i odanost jugoslovenskoj ideji, odnosno kako su statusi/identiteti Beograđanina i Jugoslovena uspostavljali kroz uzajamno potvrđivanje: „U samoj stvari g. Rosandić je odavno stekao pravo čistog Beograđanina. Još pre rata on je došao u Beograd. Njegovo jugoslovenstvo je prekaljeno. Bez zabluda i bez predrasuda." ${ }^{\text {" } 2} \mathrm{U}$ ovom članku, verovatno prvi put u Politici, iznosi se i velika zamisao T. Rosandića o podizanju „džinovskog" spomenika Kralju Petru i svima onima koji su ugradili svoje živote u jugoslovensko oslobođenje i ujedinjenje. Tu zamisao podnaslov članka imenuje kao „Panteon tvorcima naše domovine“. Tada je, međutim, Rosandić bio uveren da je mesto ovome spomeniku u Beogradu, i to ,jedino u beogradskom Gradu“.43

U mnogim od napisa o splitskim umetnicima, ostrvo Brač igra posebnu ulogu. Zanimljivo je da je i za Rosandića i za Ignjata Joba tu ulogu imalo isto mesto na Braču, Supetar. Brač je i svojevrsni produženi prostor Grada, Splita, sa svojim naseljima, poput pomenutog Supetra, ali prostor (dalmatinske) Prirode. Tačnije, sami umetnici čine da se, kao u utiscima Marka Cara o neponovljivoj harmoniji splitske prirode i arhitekture, dva suprotna entiteta sjedine u istoj takvoj harmoniji. Rosandić je tako u Supetru izgradio mauzolej obitelji Mate Petrinovića trudeći se da ostvari saglasje oblika mauzoleja sa „južnjačkom prirodom Dalmacije“. Politika prenosi i autopoetičku izjavu umetnika po kojoj Rosandić u gradnji mauzoleja nije unapred izabrao određeni stil, već je samo „hteo da se jadransko sunce ne lomi o odsečne uglove fasade “ ${ }^{44}$

U $S K G$-u Isidora Sekulić, u studiji koja precizno i sa zadivljujućim senzibilitetom opisuje duh i skulpturu umetnika Tome Rosandića, ${ }^{45}$ prvo apostrofira Rosandićev dalmatinski identitet kao ključni faktor njegove umetnosti i poetike: „Dalmatinac Rosandić poznao je rano daljine, poeziju mora, statiku i čulnu opipljivost kamena. Po vokaciji skulptor, imao je

\footnotetext{
$\overline{41}$ М. РААОВАНОВИЋ, „Један велики наш уметник, (- г. Тома Росандић остаје у Београду - Његов Маузолеј на Брачу - Како он замишьа наш народни Пантеон)“, Политика (Beograd), br. 6907, 22. 7. 1927., 6.

42 Isto.

43 Isto.

44 Isto.

45 Исидора Секулић, „Анамитички моменти. Тома Росандић, юегов дух и скулnтура“, СКГ, 1940., br. 5, 355-359.
} 


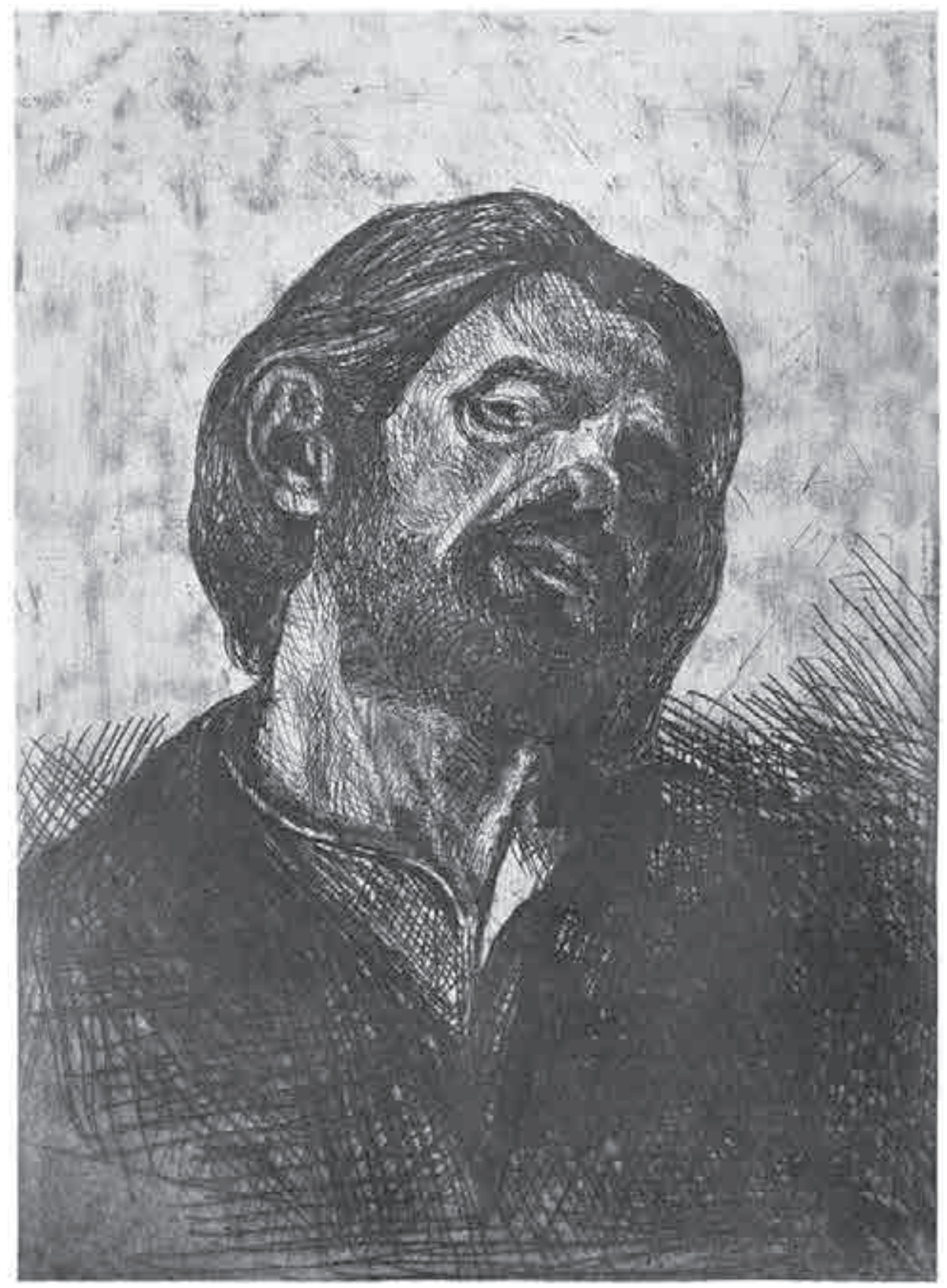

Sl. 3. Autoportret Tome Rosandića

je dakle, sreću da dođe na svet gde treba: gde će pogledom proučavati prostorne tajne, i gde će osetljivim svojim rukama pipati kamen." ${ }^{46}$ 
Međutim, nisu svi splitski umetnici o kojima je $S K G$ pisao imali tu sreću da o njihovom delu govore oni koji će razumeti značaj njihovog porekla. ${ }^{47}$ Takav je slučaj bio sa drugim „lutajućim“ splitskim i jugoslovenskim umetnikom, Marinom Tartaljom. Za Branka Popovića, saradnika $S K G$-a, koji prikazuje zajedničku izložbu Tartalje i Stojanovića, Tartalja je beogradski umetnik. Upadljivo „nebeogradsko“ ime splitskog slikara (koje Popović, uzgred rečeno, piše kao Marin a ne Marino) gotovo da obavezuje kritičara na makar usputnu informaciju o njegovim počecima u rodnom gradu. Upadljivo je, međutim, koliko Popović ograđuje rad obojice jugoslovenskih umetnika i moguće domete izložbe prostorom prestonice: „Ova izložba dvojice beogradskih mlađih umetnika, lepo uređena i umetnički veoma uspela, ima sve uslove da privuče najveću pažnju prestoničke kulturne publike. “48 Da Tartalja ima ikakve veze sa primorjem i Mediteranom, može se jedino naslutiti iz uzgrednog pominjanja slike „Masline“, zajedno sa još jednom grupom slika „sirovih pejzaža“.

Specifična je u tom smislu pozicija Ignjata Joba. Fizički vezan više za Supetar nego za sam grad Split, i više za Srbiju nego za sam Beograd, Job ipak pripada krugu splitskih i beogradskih umetnika, ali se zato pre svega ostvaruje kao jugoslovenski umetnik. Smrt Ignjata Joba, tačnije posthumna izložba koja se na godišnicu slikareve smrti održavala u Beogradu, intenzivirala je pisanje Politike o njemu. Zaredom se javljaju dva članka. U prvom, „Umrli slikar govori o sebi““49 ponovljeni su uglavnom delovi iz mnogo ranijeg intervjua, „Slikar koji kopa zemlju. Ignjat Job, slikar i vizionar priča nam o svome čudnom životu“, načinjenog u vreme kada Job još nije živeo u Supetru (ali će se već te godine vratiti u Dalmaciju, što je i nagovestio u intervjuu). ${ }^{50}$

Ignjat Job intrigirao je pažnju beogradske javnosti pre svega snagom svog slikarskog izraza, a zatim i neobičnog života. Ipak, slikar i njegovo delu jesu i nenemetljivo i implicitno oličenje integralnog jugoslovenstva, i to više u kulturnom smislu a daleko manje u političkom. Jugoslovenski prostor Job je objedinio svojim životom i selidbama, a kroz pisanja Politike se može pratiti njegovo kretanje od sela Kulina ispod planine Jastrebac (Srbija) do Splita tj. Supetra. Njegove slike, širina njihovih motiva, oslikavaju posredno i istoriju i geografiju Jugoslavije. Pjer Križanić vidi ga i kao gotovo alegorijsku figuru martirski na(ra)stajuće jugoslovenske kulture: „Najsnažnija dela našega slikarstva izašla su iz te neprekidne borbe sa demonom, njegovim ličnim i demonom naše stvarnosti, da najzad, pre nepunu godinu dana, u zagrebačkoj klinici podlegne taj velikomučenik naše mlade kulture." ${ }^{\text {"S1 }}$

\footnotetext{
$\overline{47}$ Temu posebnog (književno)istoriografskog rada predstavljalo bi istraživanje uzroka oskudnog prisustva članova porodice Desnica u $S K G$-u tokom međuratnog perioda. Naime, Uroš Desnica javlja se u $S K G$-u jednim člankom koji predstavlja odgovor na jednu od anketa časopisa, Vladan Desnica se pojavljuje kao tema, tj. spominje se kao urednik Magazina Sjeverne Dalmacije, u prikazu ovog almanaha iz pera Stanislava Vinavera, a samo se Boško Desnica pojavljuje kao suvereni autor članka. Videti: Станиша ВОЈИНОВИЋ, Сриски къижевни гласник 1920-1941. Библиографија нове серије, Beograd - Novi Sad 2005. Iako naznačena tema i pomenuti članci jesu važni i za temu ovoga rad, od njihove analize se odustalo zbog toga što bi zahtevali ukuljučivanje dodatne građe i argumentacije i time bitno proširili obim teksta.

48 Бранко ПОПОВИЋ, „Изможба слика Марина Тартање и скулптура Сретена Стојановића“, СКГ, 1929., knj. 26, br. 6, 461 .

49 Игњат ЈОБ, „Умрли сликар говори о себи“, Политика (Beograd), br. 10363, 30. 3. 1937., 10.

50 М., „Сликар који копа заемьу. Игњат Јоб, сликар и визионар, прича нам о своме чудном животу“, Политика (Beograd), br. 6897, 12. 7. 1927., 6.

51 П(јер) КРИЖАНИЋ, „Уметност Игњатија Јоба. Поводом његове постхумне изможбе“, Политика (Beograd), br. 10366, 2. 4. 1937., 9. Kurziv S. B.
} 
Posle prvog perioda (moglo bi se reći perioda traženja i stradanja, koji se okončava smrću Jobovog deteta u selu u Srbiji gde je sa suprugom živeo), odnosno prvog segmenta posthumne izložbe, dolazi drugi:

I onda put na more, na sunce među male ljude, ribare, osobenjake i bezazlene. Izišavši iz mraka i teskobe velikovaroškog života koji je on teško podnosio, njegove slike postaju svetlije, vedrije i radosnije. Na izložbama se viđaju sunčani pejzaži „Supetra“ i njegovi divni maslinjaci. U tim slikama se prvi put javlja svetli kolorit, čista kao burom očišćena atmosfera primorskih predela. (...) Boja peva. Karakteristična dela iz tog vremena jesu Proleće, Masline, Predeo i Komiža..$^{52}$

Za Križanića je ,jedna od naših mnogobrojnih sramota“ to što Job nije za života boravio u Parizu. ${ }^{53}$ Međutim, upravo se iz redova koje je i sam Križanić pisao, nameće misao da jugoslovenski karakter Jobove umetnosti i ličnog stradanja ne bio tako upečatljiv da se umetnik otisnuo drugim profesionalnim i životnim putevima.

\section{ZAKLJUČCI}

Grad Split i znameniti Splićani u beogradskoj su javnosti, odnosno jednom njenom delu, često smeštani unutar diskursa jugoslovenskog integralizma, pri čemu su sam grad, pojedini događaji koji su se u njemu odigravali pa čak i umetnička dela Splićana bili tumačeni kao izrazi jugoslovenskog jedinstva, nacionalnog oslobođenja i, kod splitskih autora/dopisnika posebno, kao izraz otpora italijanskim pretenzijama. Posebno je vredno isticanja da je upravo u trenucima kada je reč dala Splićanima i učestvovala u „splitskoj“ polemici, Politika, a sa njom i beogradska javnost, osvešćivala i sopstvenu poziciju i ulogu, kroz rečenice koje čak anticipiraju kasnija teorijska promišljanja javnosti. U tim tekstualnim trenucima beogradska javnost uspela je da se ostvari kao dosledno jugoslovenska.

Jedan od mogućih odgovora na pitanje da li su svi uočeni napisi i diskursi o Splitu i Splićanima uticali, makar i delom, na odluku V. Desnice da u Splitu pokrene poseban (sub)regionalni, severnodalmatinski periodik - jeste da su mogli uticati, jer su svojim suženim fokusima i pogledima „spolja“ izazivali još jedan dodatni odgovor ,iznutra“, uprkos činjenici da su i Split i Dalmacija u tom trenutku imali bogatu periodičku produkciju. S druge strane, u fokusiranjima beogradske štampe „ošetećena“ je više šira okolina grada, specifični problemi zaleđa, pa i gradske teme lokalnijeg značaja, a manje sam Split, koji je kao mesto prirodne i urbanističke lepote, intenzivne modernizacije i živog kulturnog života izazivao pažnju beogradske javnosti i dobio u njoj, koliko je u medijskom jeziku uopšte moguće, prilično vernu i iznijansiranu sliku. Ipak, čini se da bi ta slika bila daleko vernija i ubedljivija da je u njenom oblikovanju učestvovao i V. Desnica.

22 Isto.

53 Kurziv S. B. 


\section{$\cos$}

\section{Split People and Split Themes in Belgrade Public OPINION IN I920-I94I (POLITIKA AND SRPSKI KNJIŽEVNI GLASNIK)}

Starting from a reductive understanding of interwar Belgrade public opinion (represented here by the daily Politika and the journal Srpski književni glasnik), several (expected) conclusions can be made. The city of Split and the prominent people of Split were often placed in Belgrade public discourse in the context of Yugoslav integralism, whereby the city itself, particular events taking place in it, and even works of art created by Split artists were interpreted as expressions of Yugoslav unity, national liberation, and in some authors/correspondents from Split, also as an expression of resistance to Italian claims. The discourse on Split in Politika was not homogeneous, and sometimes it even contained clashing positions, but it is interesting that in terms of style they have in common a device of personification. The clashing attitudes of Belgrade authors range from the greatest sympathies for the city to (semi)open hostility. This amplitude also had a diachronic dimension, since it was also conditioned by socio-historical changes, that is, changes in dominant public opinion from the initial state-building enthusiasm of the early 1920s to the scepticism of the late 1930s. People from Split, however, also wrote for Politika on Split themes. It is precisely at the moments when it publishes articles by the residents of Split and when it takes part in a "Split" polemic (Grisogono, Rosandić), that Politika and the Belgrade public in general becomes aware of its own position and role, in sentences that even anticipate later theorizations of the public. In these textual moments the Belgrade public discourse manifests itself as consistently Yugoslav. Srpski književni glasnik, which was less interested in the city, and more in the people of Split, focused more on particular artistic phenomena and individual authors, whose Split background was not always remembered. A possible answer to the question of whether such writing and discourse on Split in Belgrade public opinion may have influenced, at least in part, Vladan Desnica's decision to launch a special (sub) regional, northern Dalmatian periodical, is that it may have had an influence, since due to their narrow focus and views from the "outside" it provoked yet another response from the "inside", in spite of the fact that both Split and Dalmatia had at that point a rich production of periodicals. On the other hand, the perspectives of the Belgrade press did more "wrong" to the broader area of the city, the specific problems of the hinterland, and even the city themes of a more local significance, but less so to the city of Split itself, which, as a place of great natural and urban beauty, of intensive modernization and vibrant cultural life, attracted the attention of the Belgrade public, and which received in its discourse, to the extent to which this is even possible in the language of the press, a fairly realistic and nuanced image. However, it seems that the image would have been far more realistic and persuasive had Vladan Desnica participated in the shaping of it.

Key words: Split, people of Split, Vladan Desnica, Belgrade public opinion, Politika, Srpski književni glasnik 


\section{$\cos$}

\section{Izvori i literatura}

Niko Bartulović, Jadranska antologija, Split 1934.

Гр[игорије] БОЖОВИЋ, „Утисци из данашњег Сплита“, Политика (Beograd), br. 11181, 19. 7. 1939., 17.

В[инко] БРАЈЕВИЋ, „Кнез Павие је јуче открио споменик Гргуру Нинском у Спииту“, Политика (Beograd), br. 7690, 30. 9. 1929., 1-2.

Марко ЦАР, „Град царских ьетовања“, Политика (Beograd), br. 6879, 24. 6. 1927., 7.

Marko CAR, „Grad carskih ljetovanja“, Novo doba (Split), br. 147, 27. 6. 1927., 2.

Марко ЦАР, „Утисци из Сплита“, Политика (Beograd), br. 5130, 6. 8. 1922., 1-2.

Marko CAR, „Utisci iz Splita“, Novo doba (Split), br. 182, 12. 8. 1922., 2-3.

Dušan Đurić, „Politika“, Novinarska enciklopedija (ur. Dušan Đurić), Beograd 1997., 527-528.

Ђуро ГАВЕАА, „Аирика Тина Ујевића“, Политика (Beograd), br. 10614, 11. 12. 1937., 14.

Првислав ГРИЗОГОНО, „ГАе Аа се подигне бановинска палата у Сплиту“, Политика (Веоgrad), br. 10031, 26. 4. 1936., 10.

ВАадимир ГВОЗАЕН, Српска путописна култура 1914-1940. Студија о хронотопичности cycpema, Beograd 2011.

Zdravka Jelaska Marijan, Grad i ljudi: Split 1918.-1941., Zagreb 2009.

Игњат ЈОБ, „Умрми сликар говори о себи“, Политика (Beograd), br. 10363, 30. 3. 1937., 10.

Duško Kečкемet, Bibliografija o Splitu. Dio 2: Od 1860. - 1955. godine, Split 1956.

Пјер КРИЖАНИЋ, „Марин Тартажа“, Политика (Beograd), br. 7752, 3. 12. 1929., 8.

П[јер] КРИЖАНИЋ, „Уметност Игњатија Јоба. Поводом његове постхумне изложбе“, Политика (Politika), br. 10366, 2. 4. 1937., 9.

Ivanka Kuıć, „Novo doba - najvažniji splitski i dalmatinski list između dva rata“, Kulturna baština, 39/2013., 113-138.

M., „САикар који копа заемьу. Игњат Јоб, сликар и визионар, прича нам о своме чудном животу“, Политика (Beograd), br. 6897, 12. 7. 1927., 6.

М. РААОВАНОВИЋ, „Један вемики наш уметник, (- г. Тома Росандић остаје у Београду Његов Маузолеј на Брачу - Како он замишьа наш народни Пантеон)“, Политика (Веоgrad), br. 6907, 22. 7. 1927., 6.

Бранко ПОПОВИЋ, „Изложба слика Марина Тартање и скулпутура Сретена Стојановића“, Српски књижевни гласник, 1929., knj. 26, br. 6, 461.

Drago Roksandić - Ivana Cvijović Javorina, „Riječ unaprijed“, Vladan Desnica i Split 1920. 1945. Zbornik radova sa znanstvenog skupa Desničini susreti 2014, Zagreb 2015., 7 -12.

Тома РОСАНАИЋ, „Како би требало да изгледа народни споменик у Сплиту“, Политика (Beograd), br. 10051, 17. 5. 1936., 9.

Тома РОСАНТИЋ, „Мора се стречити зидање палате на месту са кога би закмонима половину Аиокиецијанове палате“, Политика (Beograd), br. 10041, 7. 5. 1936., 13.

Petar PožAr, Znameniti i zaslužni Splićani te spomena vrijedne osobe u splitskoj povijesti (1700 godina), Split 2001.

Ст. РОЦА, „На данашњи дан ушла је српска војска у Спиит“, Политика (Beograd), br. 11664, 21. 11. 1940., 6.

Исидора СЕКУАИЋ, „Аналитички моменти. Тома Росандић, његов дух и скулптура“, Српски книжевни гласник, 1940., br. 5, 355-359. 
Араги А. ТОАОРОВИЋ, „Спиит као граА велике будућности“, Време (Beograd), br. 5314, 30. 10. 1936., 6.

„Умро је Франо Булић, наш славни археолог“, Политика (Beograd), br. 9411, 31. 7. 1934., 5.

Станиша ВОЈИНОВИЋ, Српски къижевни гласник 1920-1941. Библиографија нове серије, Веograd - Novi Sad 2005. 